\title{
General Psychiatry Olanzapine-induced acute necrotising pancreatitis leading to recurrent multiple organ dysfunction syndrome
}

\author{
Stelios Naxakis (i) , Meghan Wafer, Ruth Collins
}

To cite: Naxakis S, Wafer M, Collins R. Olanzapineinduced acute necrotising pancreatitis leading to recurrent multiple organ dysfunction syndrome. General Psychiatry 2022;35:e100687. doi:10.1136/ gpsych-2021-100687

SN and MW are joint first authors.

Received 25 0ctober 2021 Accepted 16 February 2022

Check for updates

(c) Author(s) (or their employer(s)) 2022. Re-use permitted under CC BY-NC. No commercial re-use. See rights and permissions. Published by BMJ.

St. Michael's Unit, Mercy University Hospital, North Lee Mental Health Services, Cork, Ireland

Correspondence to Dr Stelios Naxakis; Steliosnaxakis@gmail.com

\section{SUMMARY}

A married mother in her 50s acutely developed vomiting, diarrhoea and severe epigastric pain 2 weeks following discharge from an acute psychiatric inpatient unit. She presented to the emergency department complaining of a 2-day history of the above symptoms. Blood tests revealed neutrophilia, grossly raised inflammatory markers and amylase levels triple the normal range. Based on radiological investigations, she was treated for necrotising pancreatitis that quickly escalated to multi-system organ failure and a lengthy intensive care unit admission. Common causes of pancreatitis, including cholelithiasis, alcohol and other drugs, were ruled out. Despite this, she suffered recurrent episodes of pancreatitis with significant morbidity. Olanzapine, started during her psychiatric admission, was determined to be the offending agent. Two years following the discontinuation of olanzapine, the patient has had no further episodes of acute pancreatitis.

\section{BACKGROUND}

Olanzapine has been observed and documented to be associated with acute pancreatitis. ${ }^{1-10}$ The likelihood of adverse events due to olanzapine is possible on average according to the Naranjo Scale (a validated adverse drug event rating scale). ${ }^{11}$ The likely mechanism of action is acute hypertriglyceridaemia. ${ }^{2-4}$ 6-8 The authors would like to present a case of olanzapineinduced acute pancreatitis with an aim to inform our practice: patients commencing olanzapine treatment should have triglycerides measured before treatment and monitored throughout its course. This case aims to emphasise that clinicians should be suspicious of olanzapineinduced pancreatitis when other causes are ruled out.

\section{CASE HISTORY}

A married mother of two adult children in her 50 s was referred by her general practitioner for an acute psychiatric assessment following a 2-day history of agitation, paranoia and delusions of persecution. She presented with a 2-week history of reduced appetite and insomnia, as well as an acute disturbance in her concentration and mood. The patient had no previous psychiatric history. She was diagnosed with an acute schizophrenia-like psychotic disorder (International Classification of Disease, 10th revision (ICD-10) code of F23.2) and voluntarily admitted to the acute mental health unit where she was prescribed olanzapine $10 \mathrm{mg} /$ night. She remained an inpatient for a total of 20 days. During this time, baseline blood investigations including a complete blood count, renal profile, liver profile and fasting lipid profile were reported as within normal limits. She was discharged on olanzapine $10 \mathrm{mg} /$ night and sertraline $100 \mathrm{mg} /$ day. Community follow-up was arranged.

Two weeks following discharge from the acute mental health unit, the patient presented to the emergency department with a 2-day history of vomiting, diarrhoea and severe epigastric pain. Her medical/surgical history was unremarkable, and her only prescribed medications were those prescribed on discharge 2 weeks earlier. Collateral history from family confirmed compliance with prescribed medication with no evidence of overdose. The patient's mental state was unchanged from psychiatric discharge, and there was no evidence of acute mental illness. On examination, the patient was tachycardic with a heart rate of 135 beats per minute, hypotensive with a blood pressure of $92 / 68 \mathrm{~mm} \mathrm{Hg}$ and febrile with a temperature of $38.6^{\circ} \mathrm{C}$. Abdominal examination revealed tenderness in the epigastrium with rebound tenderness. Cardiorespiratory examination did not reveal any abnormalities. Examination of the central and peripheral nervous system was grossly intact. Initial blood tests revealed amylase of $763 \mathrm{U} / \mathrm{L}$ (reference range 40-140U/L), C reactive protein $>320 \mathrm{mg} / \mathrm{L}$ (reference range $0-5 \mathrm{mg} / \mathrm{L}$ ), white blood cells $34 \times 10^{9} / \mathrm{L}$ (reference range $\left.4 \times 10^{9}-10 \times 10^{9} / \mathrm{L}\right)$, neutrophils $31.2 \times 10^{9} / \mathrm{L}$ (reference range $2 \times 10^{9}-7.5 \times 10^{9} / \mathrm{L}$ ) 
and triglycerides of $414 \mathrm{mg} / \mathrm{dL}$ (reference range $<150 \mathrm{mg}$ / $\mathrm{dL}$ ). The patient was treated for severe sepsis, and computed tomography (CT) of the abdomen and pelvis revealed acute necrotising pancreatitis of the head and neck. The patient quickly deteriorated into multi-system organ failure, including acute renal failure requiring haemodialysis, acute respiratory syndrome requiring intubation and ventilation, and portal vein thrombosis. She remained in intensive care for 30 days receiving supportive treatment. She made a full recovery and was discharged home with regular medications unchanged from admission.

Less than a month after discharge, the patient was readmitted to intensive care unresponsive secondary to recurrent pancreatitis and Clostridium difficile infection, encephalopathy and disseminated intravascular coagulation leading to haemorrhagic shock. Again, there was no evidence of acute relapse of psychosis. Collateral history reported compliance with medications including olanzapine $10 \mathrm{mg} /$ night. She spent two more months in intensive care but again made a full recovery.

One month post-discharge from the second intensive care unit admission, the patient again presented to the emergency department with a radiographic confirmed acute pancreatitis complicated by bowel ischaemia requiring resection and ileostomy. The following 8-month hospitalisation-spent between intensive care and the general surgical ward-was complicated by a hospital-acquired infection, but the patient again ultimately made a full recovery. In addition, she required extensive multidisciplinary rehabilitation to improve her mobility and function in activities of daily living, which continued after discharge to her home. The patient was seen by liaison psychiatry during her surgical admission. They recommended a change in her antipsychotic therapy due to the risk of olanzapine-induced pancreatitis. The patient was given a trial of aripiprazole $10 \mathrm{mg} /$ day and then continued on that medication. She has had no further episodes of pancreatitis. Her mental health has remained stable without relapse, and she is engaging well with her community mental health team.

\section{INVESTIGATIONS}

Results discussed in the above case history are included below.

\section{Imaging on the first medical presentation to emergency department}

CT abdomen and pelvis on first medical presentation: acute pancreatitis with parenchymal necrosis of head and neck. No acute peripancreatic collections. Cholethiasis.

Magnetic resonance cholangiopancreatiography (MRCP): haemorrhagic exudative peripancreatic phlegmon with acute necrotic pancreatitis. No acute peripancreatic collection. Cholelithiasis but no MRCP evidence of choledocholiathiasis.

Imaging on the second medical presentation to emergency department

CT abdomen and pelvis: the body and the tail of the pancreas appear viable. The head, neck and uncinate processes of the pancreas are necrosed. Calcified stones are present in the gallbladder. No biliary or pancreatic ductal dilation.

\section{Imaging on the third medical presentation to emergency} department

CT abdomen and pelvis: necrosis of head, body and neck of the pancreas. Gallstones, no CT features of cholecystitis or biliary obstruction.

MRCP: uncomplicated gallstones. No bile duct calculi.

\section{DIFFERENTIAL DIAGNOSIS}

The primary diagnosis for the above case is olanzapineinduced acute necrotising pancreatitis.

Common causes of pancreatitis were investigated and excluded in each presentation, including alcohol, drugs and biliary obstruction. In this case, the patient had no further episodes of pancreatitis once she transitioned to alternative antipsychotics, providing additional evidence that olanzapine was the offending agent.

\section{OUTCOME AND FOLLOW-UP}

The patient fully recovered following her third hospital admission with acute pancreatitis. The surgical team worked with her community mental health team to initiate treatment with an alternative antipsychotic, aripiprazole $10 \mathrm{mg} /$ day. The patient has not had any further episodes of pancreatitis since the medication switch. Her mental state has remained stable without relapse.

\section{DISCUSSION}

Acute pancreatitis has been documented to be a possible adverse drug reaction of olanzapine. A literature review was conducted to collate published articles addressing this question.

The authors searched PubMed with Boolean terms: 'acute OR necrotising' AND 'pancreatitis' AND ‘olanzapine'. Results of the search produced 26 full-text articles. One paper was duplicated, 2 did not have English translations and 13 were irrelevant to the literature review question. In total, 10 articles published between 1999 and 2018 were identified: 8 case reports and 2 case series. Demographics varied widely among described patients: aged 22-72 years and $75 \%$ male.

Please see table 1 for a summary of documented cases of olanzapine-induced pancreatitis. There were multiple indications for olanzapine treatment, including bipolar disorder, schizophrenia, schizoaffective disorder, cognitive impairment and 
Table 1 Summary of olanzapine-induced pancreatitis cases included in the literature review

\begin{tabular}{|c|c|c|c|c|c|c|c|c|}
\hline Study & Sex & Age & Diagnosis & $\begin{array}{l}\text { Olanzapine } \\
\text { dose }\end{array}$ & $\begin{array}{l}\text { Duration of } \\
\text { olanzapine } \\
\text { treatment }\end{array}$ & Alcohol & $\begin{array}{l}\text { Triglyceride level } \\
\text { (mg/dL, reference } \\
\text { range }<150 \text { ) }\end{array}$ & $\begin{array}{l}\text { Outcome (once } \\
\text { olanzapine } \\
\text { discontinued) }\end{array}$ \\
\hline Baysal et al $\left.\right|^{1}$ & M & 44 & Schizophrenia & $10 \mathrm{mg} /$ day & 3 weeks & None & - & Full recovery \\
\hline Bracamonte et $\left.\mathrm{a}\right|^{3}$ & $\mathrm{~F}$ & 69 & Bipolar disorder & $10 \mathrm{mg} /$ day & 22 months & - & 92 & Full recovery \\
\hline Buszek et al ${ }^{4}$ & M & 36 & Bipolar disorder & $20 \mathrm{mg} /$ day & 6 weeks & None & 5185 & Full recovery \\
\hline Kerr et $a l^{5}$ & M & 52 & $\begin{array}{l}\text { Schizoaffective } \\
\text { disorder }\end{array}$ & $20 \mathrm{mg} /$ day & 1 year & Occasional & - & Full recovery \\
\hline Samanta et $a l^{6}$ & M & 32 & Bipolar disorder & $10 \mathrm{mg} /$ day & 2 months & None & 560 & Full recovery \\
\hline Vaidyanathan et al $l^{7}$ & M & 25 & $\begin{array}{l}\text { Paranoid } \\
\text { schizophrenia }\end{array}$ & $15 \mathrm{mg} /$ day & 14 days & None & 163 & Full recovery \\
\hline
\end{tabular}

neuropsychiatric symptoms of multiple sclerosis. Duration of treatment with olanzapine varied from 6 weeks to 2 years, with doses ranging from 5 to 20 $\mathrm{mg} /$ day in both tablet and oral dispersible administration form. Clinicians in all cases were confident in ruling out any confounders of acute pancreatitis, in particular alcohol, gallstones and other drugs. The majority of the cases made use of radiological investigation to rule out cholelithiasis ${ }^{1-8}$ (one exception was a patient with a previous history of cholecystectomy within the decade prior to presentation $\left.{ }^{9}\right)$. In addition, a concurrent accidental verapamil overdose may have confounded one case, but the authors proposed that olanzapine was the causative agent. ${ }^{9}$

Hypertriglyceridaemia was the most common proposed cause of olanzapine-induced acute pancreatitis. Seven cases measured and documented acute hypertriglyceridaemia in the context of olanzapine use. $^{4-8}$ Plasmapheresis was required and integral to recovery in one patient with a profoundly raised triglyceride level. ${ }^{4}$ Authors from gastroenterology recommended that patients be screened and treated for hypertriglyceridaemia prior to starting treatment with olanzapine. ${ }^{5}$

Naranjo score, a validated tool for determining the probability of adverse drug reaction, ${ }^{11}$ was discussed in multiple cases. Three case reports suggest a Naranjo

\section{Learning points}

- Clinicians should consider measuring serum triglycerides before commencing olanzapine treatment and then managing accordingly with appropriate agents.

- Patients on olanzapine treatment should be monitored for hypertriglyceridaemia.

- Clinicians should be suspicious of olanzapine-induced pancreatitis when common causes are ruled out. score between 4 and 6 correlating to either a possible or a probable association between olanzapine and adverse reaction. ${ }^{39} \mathrm{~A}$ larger case series of 41 cases of atypical antipsychotic-induced pancreatitis suggest a Naranjo score of 4 for olanzapine (possible adverse drug reaction) and that only $10 \%$ of cases between 1999 and 2015 have produced a score suggesting probable adverse drug reaction. ${ }^{10}$

Contributors SN and MW contributed equally to this paper. RC was the supervising consultant.

Funding The authors have not declared a specific grant for this research from any funding agency in the public, commercial or not-for-profit sectors.

Competing interests None declared.

Patient consent for publication Consent obtained directly from patient(s) Ethics approval This study does not involve human participants.

Provenance and peer review Not commissioned; externally peer reviewed. Open access This is an open access article distributed in accordance with the Creative Commons Attribution Non Commercial (CC BY-NC 4.0) license, which permits others to distribute, remix, adapt, build upon this work non-commercially, and license their derivative works on different terms, provided the original work is properly cited, appropriate credit is given, any changes made indicated, and the use is non-commercial. See: http://creativecommons.org/licenses/by-nc/4.0/.

ORCID iD

Stelios Naxakis http://orcid.org/0000-0003-0924-4282

\section{REFERENCES}

1 Baysal B, Kayar Y, Özmen A, et al. Olanzapine-Induced acute pancreatitis. Turk J Gastroenterol 2015;26:289-90.

2 Waage C, Carlsson H, Nielsen EW. Olanzapine-Induced pancreatitis: a case report. JOP 2004;5:388-91.

3 Bracamonte JD, Underhill M, Sarmiento P. Acute pancreatitis associated with lisinopril and olanzapine. Am J Heal Pharm 2010;67:214-6.

4 Buszek SM, Roy-Chaudhury P, Yadlapalli G. Olanzapine-Induced hypertriglyceridemia resulting in necrotizing pancreatitis. ACG Case Rep J 2016;3:e104.

5 Kerr TA, Jonnalagadda S, Prakash C, et al. Pancreatitis following olanzapine therapy: a report of three cases. Case Rep Gastroenterol 2007;1:15-20. 
6 Samanta S, Samanta S, Banik K, et al. Emphysematous pancreatitis predisposed by olanzapine. Indian J Anaesth 2014;58:323-6.

7 Vaidyanathan S, Subramanian K, Bharadwaj B, et al. Acute necrotizing pancreatitis associated with orally disintegrating formulation of olanzapine: implications on clinical presentation and management. J Clin Psychopharmacol 2019;39:519-21.

8 Rossor AM, Leech N, Neely RDG. Olanzapine-induced chylomicronemia presenting as acute pancreatitis. $J$ Clin Psychopharmacol 2007;27:395-6.
9 Doucette DE, Grenier JS, Roberston PS. Olanzapine-Induced acute pancreatitis. Ann pharmacother 2000;34:1128-31.

10 Silva MA, Key S, Han E, et al. Acute pancreatitis associated with antipsychotic medication: evaluation of clinical features, treatment, and polypharmacy in a series of cases. J Clin Psychopharmacol 2016;36:169-72.

11 Naranjo CA, Busto U, Sellers EM, et al. A method for estimating the probability of adverse drug reactions. Clin Pharmacol Ther 1981;30:239-45.

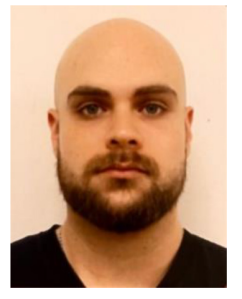

Dr Stelios Naxakis completed undergraduate studies at York University, Toronto, Canada, obtaining a bachelor of science in psychology. He attended Semmelweis School of Medicine in Budapest, Hungary prior to immigrating to Cork, Ireland. He currently is a higher specialist trainee and senior registrar in psychiatry with the Irish College of Psychiatry under the University College Cork Deanery, Ireland. He is also a member of the College of Psychiatrists Ireland, the UK Balint Society, and a graduate master student at the Royal College of Physicians Ireland. Previous accolades include obtaining a national scholarship through the National Doctors Training and Planning fund for his master's degree in clinical leadership and management. 